\title{
THE ROLE OF BRAND AWARENESS MEDIATES THE RELATIONSHIP CREDIBILITY BETWEEN ENDORSER AND ONLINE PURCHASE INTENTION THROUGH ONLINE SHOPPING SITE BUKALAPAK.COM
}

\author{
AA Sagung Ksanthi Paramhita \\ Faculty of Economics and Business, Udayana University (Unud) \\ Ni Made Purnami \\ Faculty of Economics and Business, Udayana University (Unud) \\ madepurnami@unud.ac.id
}

\begin{abstract}
This study aims to find out how the role of brand awareness mediates the relationship of endors er credibility with online purchase intention by using the online shopping site Bukalapak.com. The location of research was in Denpasar City with the number of respondents 110 people. Data analysis techniques used are Path Analysis. The results show, brand awareness has a positive and significant effect on purchase intention. Celebrity endorsers have a positive and significant effect on brand awareness. Celebrity endorsers have a positive and significant effect on purchase intention. Brand awareness able to mediate the influence of celebrity endorser on potential purchase Bukalapak.com.
\end{abstract}

Keywords: brand awareness, endorser credibility, online purchase intention.

\begin{abstract}
Abstak
Penelitian ini bertujuan untuk mengetahui bagaimana peran brand awareness memediasi hubungan kredibilitas endorser dengan niat pembelian online dengan menggunakan situs belanja online Bukalapak.com. Lokasi penelitian berada di Kota Denpasar dengan jumlah responden 110 orang. Teknik analisis data yang digunakan adalah Path Analysis. Hasil penelitian menunjukkan, kesadaran merek memiliki pengaruh positif dan signifikan terhadap niat beli. Pendukung selebriti memiliki efek positif dan signifikan terhadap kesadaran merek. Pendukung selebriti memiliki efek positif dan signifikan terhadap niat pembelian. Kesadaran merek mampu memediasi pengaruh endorser selebriti pada potensi pembelian Bukalapak.com
\end{abstract}

Kata Kunci: kesadaran merek, kredibilitas endorser, niat pembelian online.

JEL: M31

\section{Research Background}

The use of celebrity endorsers in communicating a product has become a trend used by companies in product marketing and corporate image development. Celebrity endorsers have the potential to attract the attention of consumers and make products more prominent than other similar products (Gupta et al. 2015). The importance of attractiveness of advertising aims to grow brand awareness in consumers, if consumers already have high awareness it will affect the attitudes and consumers' awareness of the brand (Kiswati 2010). The existence of an advertisement must be supported by a celebrity endorser. Celebrity endorsers are people who demonstrate a product or service that will be displayed in an ad. There are two types of 
endorsers according to Shimp (2014: 335), namely celebrity endorsers and non- celebrity supporters ( typical-person endorsers ). These endorsers must have some criteria, such as attractiveness and credibility to be able to attract the attention of the consumers through the physical, intellectual, lifestyle, and also the expertise possessed by the endorser in accordance with the product or service to be advertised. Endorser's credibility has three attributes, namely attractiveness, trustworthiness and expertise. Attractiveness refers to the attractiveness of an endorser. Trustworthiness refers to honesty, integrity and can be trusted. Expertise refers to the knowledge, experience, or skills possessed by endorsers relating to the product being advertised.

Brand awareness can be influenced by endorser's credibility which is expected to influence purchase intention. Brand awareness is the ability of a brand to emerge in the minds of consumers when thinking about a particular product and how easily the brand is mentioned (Chandra, 2017). Brand awareness refers on the way to realize the potential customers as well as the current consumer of a product or service that can be measured via unaware brand, brand recognition, brand recall and top of mind (Merriska and Purnanegara 2012).

Through print or electronic media, companies can communicate about the products or services through an ad that is interesting for consumers or potential consumers want to try and repurchase. Without advertising, various products are not going to be able to flow in smoothly to the distributor or seller, even to consumer or user. Many business firms are using advertising as a media of communication. Advertising is any form of presentation and promotion of ideas, goods or services in non -Personal passphrase or use certain sponsor that require a payment transaction (Kotler and Armstrong 2012). Ads that are used as promotional media shown to have a role that is crucial in introducing a brand (Gunawan and Dharmayanti 2014).

PT. BukaLapak.com uses Mohammad Istiqamah Djamad, a well-known Indonesian vocalist , Payung Teduh. The band was very popular with the song that is titled "Akad". The man who was born on January 24, 1984 has made many songs along with his band. The band itself has been formed since 2007. The existence of advertising about products or services using celebrity endorsers is expected to increase purchase intention in order to create a purchase. Purchase intention is the possibility of consumers to plan or are willing to buy products or services in the future, the increase in purchase intention also mean the possibility to purchase increasing (Kristyamoko and Andjarwari 2015). The consumers' decision to buy is influenced by the value of a product to be evaluated, as if the benefits of the product or service are felt more than sacrifice and to get it, the motivation to buy the product or service is higher. It happens also on the contrary, if the benefits are felt much smaller than the sacrifice that is issued, usually the buyer will refuse to carry out the purchase and switch to another product that is similar.

Rapid technological developments, especially in the field of telecommunications such as smartphones with increasingly diverse facilities make the world as if only in the grip. With a smartphone someone can share information such as writing, picture bars, and videos with others, even someone can shop, pay utility bills, and learn. With the diversity of the functions of the smartphone, it provides an opportunity for the perpetrators of the business transform and sell products or services over the internet. Business activities that utilize this technologyis called the e-commerce. E-commerce is the activity of buying and selling goods or services through an electronic network, which is generally via the internet (validnews.co).

Table 1. Online Buying and Selling E-Commerce Sites in Indonesia

\begin{tabular}{lll}
\hline Brand & TBI $(\%)$ & TOP \\
\hline OLX.co.id & 28.9 & TOP \\
Lazada.co.id & 18.0 & TOP \\
Tokopedia.com & 13.4 & TOP
\end{tabular}




$\begin{array}{ll}\text { Bukalapak.com } & 6.8 \\ \text { Elevania.co.id } & 1,2\end{array}$

Source: www.topbrand-award.com, 2016

OLX.co.id is an online trading site that has a Top Brand Index (TBI) most highest, namely by $28.9 \%$ in Indonesia. The percentage proves that OLX.co.id have the highest brand awareness in the minds of consumers, sinceOLX.co.id is online shopping site that exist in Indonesia. OLX.co.id used to have the name Toko Bagus which was later changed in 2014. There are five online buying and selling sites that have the highest brand awareness in Indonesia including OLX.co.id, Lazada.co.id, Tokopedia.com, BukaLapak .com and Elevania.co.id.

Bukalapak is one of the online marketplace that exist in Indonesia and is run by PT. Bukalapak. The business model that is run by PT. Bukalapak is a custumer-to-custumer (C2C) business model. BukaLapak provides consumer-to-consumer sales facilities in Indonesia. Anyone can open a shop, then serve prospective buyers from all over Indonesia, both those who order retail and wholesale. Users of this site can buy and sell products, both new and second-hand, such as bicycles, cell phones, equipment of baby, supplies agriculture, clothing, computers, and others. PT. BukaLapak was founded by Achmad Zaky who is now the CEO and Nugroho Herucahyono who serves as CTO. The company was established on January 10, 2010 which is based in Jakarta. However, BukaLapak only became a limited liability company (Perseroan terbatas/ PT) in September 2011. In March 2014, BukaLapak announced the launch of a mobile application for Android.

Launching the BukaLapak application through the company's smartphone then did a massive promotion to attract the attention of consumers. This is done to attract the attention of consumers, so they are aware of the existence of online buying and selling sites that can be accessed with smartphones and have many advantages in them. The writer chose BukaLapak in this research because BukaLapak is an online shopping site that embraces the SMEs that exist in Indonesia in order to be able to expand its market, BukaLapak also an online shopping sites originating from Indonesia and is not a network of online shopping sites like Lazada.co.id that is part of the Lazada International Group (Lazada Malaysia, Lazada Thailand, Lazada Indonesia, Lasada Philippines, and Lazada Vietnam)

The survey was conducted on Youtube ads, advertising done by BukaLapak.com which has viewer more compared with ads that performed by Lazada.co.id, but in Table 1 Lazada.co.id received ratings of both categories of online selling sites in Indonesia with brand awareness as much as $18,0 \%$, whereas Lazada.co.id established in 2012 after BukaLapak.com berdiri. This research also took pre survey of 30 people in the city of Denpasar. Pre-survey was conducted by interviews with respondents by asking some questions and statements regarding BukaLapak.com. The following are the results of a pre-survey of 30 people in Denpasar City.

Based on primary data were obtained through the pre-survey in Denpasar, known that there were 22 respondents who stated that the celebrity endorser who used BukaLapak.com have played a match against the ads and products are marketed. The respondents were also aware BukaLapak.com as the site of shopping online that can be accessed via smartphone. There are 30 those respondents who stated that they know the existence of BukaLapak.com as an online shopping site which means that all respondents in the survey pre already aware of the existence BukaLapak.com, but most respondents have less purchase intention through BukaLapak.com which numbered 19 people respondents were caused by several factors which are not be investigated.

Research that is done by Chi et al. (2009) found that brand awareness influences purchase intention. Sharifi (2014) also states that brand condition has a positive effect on purchase intention. In general, brand awareness positively influences consumer cognition, affection, and conation. Research conducted by Jung and Seock (2016) shows that the 
influence of brand awareness and perceived quality on brand attitude and purchase intention. High brand awareness affect expectations of the response that is high, and expectations of the responses have a positive effect on brand attitudes and purchase intent (Hsiao et al. 2014). Research that is done by Roozy, et al. (2014), which states that brand awareness has no effect on purchase intentions.

Finding a celebrity endorser and creating the right interpreter to speak is a matter that is very important for many companies. Ohanian (1990) developed an instrument to assess the impact of these endorsers through measurement of their credibility. Consumer attitudes toward the brand and purchase intent are influenced by advertising that features celebrities are credible where consumers are particularly vulnerable to emotional appeals that presented in the ad (Suki 2013). High celebrity attractiveness positively influences consumer purchase intentions even though the suitability of the products being marketed is relatively low compared to celebrities who have a match of products that are marketed high but have a low attractiveness (Liu 2007). Chen and Huddleston (2009) also added that the most important factor that must be possessed by an endorser is attractiveness and trustworthiness in order to create purchase intentions. From the above empirical research and surveys on BukaLapak.com ads where celebrity endorser that is done by. BukaLapak in advertising should be able to increase brand awareness which will have an impact on puschase intention. The purpose of this study is to explain the role of brand awareness to mediate the relationship between endorser credibility and online purchase intention using Bukalapak.com shopping site.

Research that is done by Permata Sari (2016) showed five factors : credibility of the celebrity endorser, the appeal of celebrity endorser, expertise celebrity endorser, trust celebrity endorser, and suitability celebrity endorser with the product has a positive and significant effect on brand awareness. The credibility variable of celebrity endorser is the variable that has the most dominant influence in brand awareness.

Celebrity endorsers attract consumers to try brands, increase brand awareness and consumption intentions (Mberia 2014). Celebrities are preferred and the fit between endorser with a brand that is advertised affect attitudes toward the brand purchase intent (Fleck et al. 2012). The effectiveness of celebrities depends on three construction sources included expertise, attractiveness and trust. The formulation of the proposed hypothesis is:

\section{awareness.}

$H_{1}$ : Celebrity endorser has a positive and significant influence on brand

Research that is done by Putra (2015) showed that celebrity endorser influence positively and significantly to the intention to buy. In the research that is done by Dei (2015) stated that the credibility of the endorser positive and significant effect on purchase intention. That is, the higher the credibility possessed by celebrity endorsers will lead to an increase in purchase intention. Pornpitakpan (2003) showed that these three dimensions (expertise, attractiveness and trust) are positively related to purchase intentions for Singapore consumers. Research conducted by Liu (2007) argued that the high power attraction of celebrities has positively influenced consumers' purchasing intentions although compatibility of products marketed relatively low compared to celebrities who have a match marketed product high but has lower power. Chen and Huddleston (2009) also added that the most important factor that must be owned by an endorser is the attractiveness and trustworthiness in order to create the intention of purchase.

$\mathrm{H}_{2}$ : Celebrity endorser has a positive and significant effect on purchase intention.

Products with high brand awarenessand a good image could promote loyalty to the brand to the consumer and with the awareness of the brand is high then, confidence in the brand will also be higher and consumer purchase intentions will also be higher. Research conducted by Eliasari (2017) stated that brand awareness has a positive effect on purchase intention. Petahiang, et al. (2015) wrote the effect of Olx online store brand awareness has a positive and significant effect on purchase intention. The same result was also stated by Wiryawan (2012) 
which stated that there was a significant influence of brand awareness variables on purchase intention that occurred at Teh Botol Sosro in the Kuningan festival market, Jakarta. Research conducted by Chi et al. (2009) found that brand awareness affects purchase intention. Sharifi (2014) also argued that brand awareness impact positively on the intention to buy, In general, brand awareness is positively affect cognition, affect, and consumers' willingness. High awareness of the brand has influence positively to the attitude of the brand and intention to buy (Hsiao, et al. 2014). A strong sense of affect recognition, recognition, and willingness affect the intent of purchase in the period ahead and encourage consumers to repeat the purchase.

H3: Brand awareness has a positive and significant effect on purchase intention

Using commercial star impact positively and significantly to brand awareness. So, it can be stated that brand awareness is very important in increasing people's buying interest. The results showed that brand awareness has a bearing on Purchase Intention. (Gunawan and Dharmayanti 2014)

\section{$\mathrm{H}_{4}$ : Brand Awarenes mediates celebrity endorser to purchase intention.}

\section{Research Method}

This research was carried out in the city of Denpasar, in the area of north Denpasar, east Denpasar, South Denpasar and west Denpasar. The number of respondents was 110 people (derived from 11 indicators $x$ 10). Path analysis was used to analyze the pattern of relationships between variables with the aim to determine the direct or indirect influence of a set of independent variables on the dependent variable .

The variables and indicators used in this study are presented in Table 2.

\section{Table 2. Research Indicators}

\begin{tabular}{llcl}
\hline \multicolumn{1}{c}{ Variable } & & Indicator & Source \\
\hline Celebrity & X1 & Attractiveness & Shimp (2014: 335) \\
Endorser & X3 & Expertise & \\
Brand & M1 & Trustworthiness & Aaker (2013) \\
awareness & M2 & Top of mind Brand & \\
& M3 & Recall & \\
Purchase & U4 & Recognition Brand & \\
Intention & Y2 & An interest in finding more information about the & Schiffman and Kanuk \\
& Y3 & product & (2004: 470) \\
& Y4 & The desire to know the product The desire to & \\
& & & \\
& & & \\
\hline
\end{tabular}

Source: Data processed, 2018

\section{Result and Discussion}

\subsection{Result}

PT. BukaLapak was established on January 10, 2010 by Achmad Zaky who initially only became a means of meeting potential between buyers with sellers for products that are more specialized in second-hand items or goods that have been used. BukaLapak also made various innovations to become one of the largest online marketplaces in Indonesia. Not only secondhand items, currently BukaLapak.com users can offer and buy a variety of products ranging from daily necessities, electronic goods, plane tickets, electricity and insurance payment services, and others.

Respondents in this study were dominated by women as many as 61.8 percent, while male respondents were 38.2 percent. The results of this distribution couldsignify that more female respondents were planning or intending to buy products on the BukaLapak.com site 
after seeing BukaLapak ads. The results of the age characteristics of the respondents in the research questionnaire showed that the respondents with the most age were respondents with the age of 18-27 years with a percentage of $60 \%$ compared to other age groups. These results indicated that respondents at the age of 18-27 were more likely to intend to make a purchase on the BukaLapak.com site. Respondents who work as private employees dominated the distribution of questionnaires with a percentage of $37.3 \%$. As many as $30 \%$ of respondents were students, $14.5 \%$ of respondents had jobs as private employees, amounting to $10 \%$ are Civil Servants, as well as housewives by $8.2 \%$.

First the instrument test is carried out, namely the validity test aims to assess the instrument used was appropriate to measure the indicators in research. The results of measuring the validity of each instrument on the variables are presented in Table 3.

Table 3. Validity Test Results

\begin{tabular}{lccc}
\hline \multicolumn{1}{c}{ Variable } & Indicator & $\begin{array}{c}\text { Pearson } \\
\text { Correlation }\end{array}$ & Information \\
\hline Celebrity Endorser & X.1 & .873 & Valid \\
(X) & X.2 & 0.796 & Valid \\
& X.3 & 0.506 & Valid \\
Brand Awareness & M.1 & 0.745 & Valid \\
(M) & M.2 & .679 & Valid \\
& M.4 & 0.839 & Valid \\
Purchase Intention & Y.1 & 0.798 & Valid \\
(Y) & Y.2 & 0.749 & Valid \\
& Y.3 & 0.748 & Valid \\
& Y.4 & .684 & Valid \\
\hline
\end{tabular}

Source: Data processed, 2018

The results of testing the validity of the instrument of research were presented in Table 3 which showed that all indicators in variabel had a value of Pearson Correlation which was greater than the figure of 0.30 , so that all indicators were said to have qualified the validity of the data. Reliability test functioned to measure the consistency of measuring devicesused. The results of the reliability measurement of each variable are presented in Table 4.

Table 4. Reliability Test Results

\begin{tabular}{lcc}
\hline Variable & Cronbach's Alpha & Information \\
\hline Celebrity Endorser $(\mathrm{X})$ & 0.690 & Reliable \\
Brand Awareness $(\mathrm{M})$ & 0.762 & Reliable \\
Purchase Intention $(\mathrm{Y})$ & .627 & Reliable \\
\hline
\end{tabular}

Source: Data processed, 2018

Instrument reliability test results in this study were presented in Table 4 which indicated that the instrument had a coefficient Cronbach's alpha which was greater than the 0.60. Then, statements in the questionnaire could be said to be reliable and the indicators used wereconsistent indicators.

The classic assumption test included tests of normality, heteroscedasticity and multicollinity nearity. Asymp.Sig value. (2-tailed) amounted to 0.460 and 0.063 . Thus, all data in both the regression equation 1 and the regression equation 2 were said to be normally distributed because the normality test valued more than 0.05 . The coefficient of tolerance was 1,000 which means greater than 0.10 and a VIF value of 1,000 that is smaller than 10 . Coefficient of tolerance amounted to 0,641 which means more substantial than 0.10 and VIF respectively by 1,560 which is smaller than 10 . These results indicated that there were no 
multikolinear symptom of regression models were created, so that the model this was worth using to predict. Sig value of variable celebrity endorser of 0,692 that is more substantial than 0.05 . Sig. Value from the celebrity endorser and brand-awareness variables respectively 0.096 and 0.100 which is greater than 0.05 so it is said to be a regression model free from heteroscedasticity symptoms.

This study used Path Analysis as its research method. This method was an extension of the multiple linear regression method to test the causality relationship between two or more variables. Here is a more detailed explanation of the stages in the path analysis test:

Table 5. Results of Analysis of Path of Regression Equations 1

\begin{tabular}{llcl}
\hline Model & R Square & lized Coefficients Beta & Sig. \\
& & & 0,000 \\
\hline Celebrity Endorser & .359 & 0.599 & \\
& & &
\end{tabular}

Based on the results of substructural path 1 analysis presented in Table 5, the structural equation is:

$$
\begin{aligned}
& M=\beta_{1} X+e_{1} \\
& M=0,599 X+e_{1}
\end{aligned}
$$

Table 6. Results of Regression Equation Path Analysis 2

\begin{tabular}{lccc}
\hline Model & R Square & lized Coefficients Beta & Sig. \\
\hline Celebrity Endorser & 0.611 & .291 & 0,000 \\
Brand Awareness & & .372 & 0,000 \\
\hline
\end{tabular}

Source: Data processed, 2018

Based on the results of substructural path analysis 2 presented in Table 6 , the structural equation is:

$$
\begin{aligned}
& Y=\beta_{2} X+\beta_{3} M+e_{2} \\
& Y=0,291 X+0,372 M+e_{2}
\end{aligned}
$$

Table 7. Direct Effects, Indirect Effects and Total Effects Celebrity Endorser (X), Brand Awareness (M), and Purchase Intention (Y)

\begin{tabular}{cccc}
\hline $\begin{array}{c}\text { Influence of } \\
\text { Variables }\end{array}$ & $\begin{array}{c}\text { Direct } \\
\text { Influence }\end{array}$ & $\begin{array}{c}\text { Indirect } \\
\text { Influence } \\
\text { Through Brand } \\
\text { awareness } \\
\left(\beta_{1} \times \beta_{3}\right)\end{array}$ & $\begin{array}{c}\text { Total } \\
\text { Influence }\end{array}$ \\
\hline $\mathrm{X} \rightarrow \mathrm{M}$ & 0.599 & - & 0.599 \\
$\mathrm{X} \rightarrow \mathrm{Y}$ & 0.291 & 0.223 & 0.514 \\
$\mathrm{M} \rightarrow \mathrm{Y}$ & 0.372 & - & 0.372 \\
\hline
\end{tabular}

Source: Data processed, 2018

Total determination value of 0.750 means that the $75 \%$ variation purchase intention affected by variations celebrity endorser and brand awareness, while the remaining $25 \%$ is explained by other factors that were not included in the model study. 


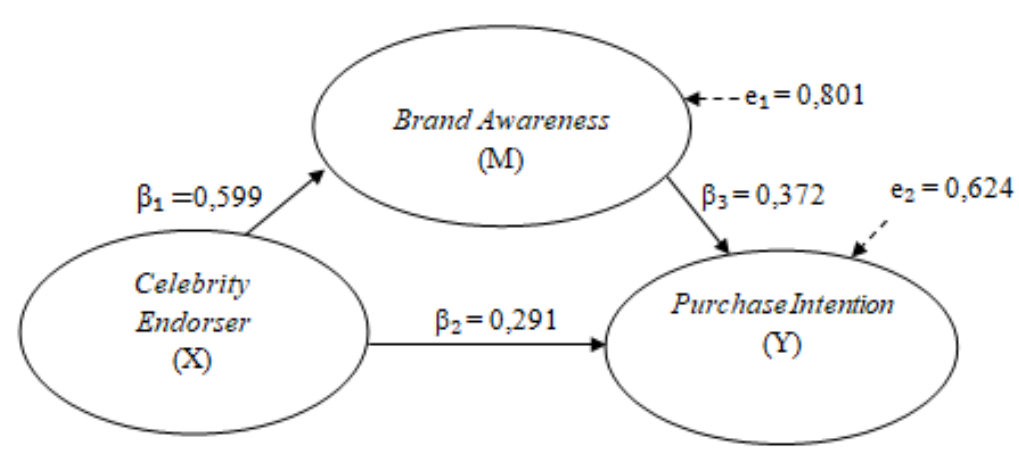

\subsection{Discussion}

Figure 1. Research Pathway Diagram Model

Tests showed that positive beta coefficient of 0.599 with a significance level of 0.000 (less than 0.05), which means $\mathrm{H}_{1}$ was received. These results indicated that the celebrity endorser variable had a positive direction and significantly influenced brand awareness. The test results showed that the higher the credibility of which is owned by a celebrity endorser or bukalapak ad star, the higher the brand awareness of consumers, so reverse it if credibility owned by celebrity endorser lower then brand awareness will be even lower. In this regard, using Mohammad Istiqamah Djamad "Payung Teduh" as a celebrity endorser is able to increase the brand awareness of BukaLapak.com in the city of Denpasar. The results of this study reinforce previous studies that have been done Gunawan and Dharmayanti (2014).

The second purpose of this study was to examine the effect of celebrity endorser on purchase intention. The test results showed that the positive beta coefficient value of 0.291 with a significance level of 0.000 (less than 0.05 ) which mean that $\mathrm{H}_{2}$ was accepted. These results indicated that celebrity endorser had a positive and significant effect on purchase intention. The interpretation of the results of the study is that if celebrity endorsers or BukaLapak ad stars have high credibility, then purchase intention will increase. Conversely, if the celebrity endorser BukaLapak was considered to have low credibility, then the purchase intention will be low. These results proved that using Mohammad Istiqamah Djamad "Payung Teduh" as a celebrity endorser is able to encourage the purchase intention of consumers in the city of Denpasar who have never bought online at BukaLapak.com. The results of the study in accordance with previous studies which prove that the celebrity endorser positive and significant effect on purchase intention as Putra (2015) and Pornpitakpan (2003) did.

The third purpose of this study was to examine the effect of brand awareness on purchase intention. The test results indicated that the positive beta coefficient of 0.372 with a significance level of 0.000 (less than 0.05 ) that $\mathrm{H}_{3}$ accepted. This result mean that brand awareness had a positive and significant effect on purchase intention. The interpretation of these results was that if consumer brand awareness in BukaLapak is high, then purchase intention will also be higher. Conversely, if BukaLapak's brand awareness is low then purchase intention will be low. In connection with these results, high brand awareness of consumers who shop online in the city of Denpasar at BukaLapak cause the enhancing on purchase intention or the intention to buy the product in BukaLapak.com. The results are consistent with several previous studies were conducted by Petahiang, et al. (2015) on the Olx 
online store that got the result that brand awareness had a positive and significant effect on purchase intention. The same results were obtained by Eliasari (2017), Wiryawan (2012) Chi et al . (2009), Sharifi (2014).

The fourth purpose of this study was to examine the role of brand awareness in mediating the effect of celebrity endorsers on purchase intention. The results of testing the indirect effect of celebrity endorser on purchase intention through brand awareness obtained a smaller coefficient than the direct effect of $0.223<0.291$. Meanwhile, the test with Sobel test showed that the value of $t$ count equal to 5,431 that is greater than table as much as 1,982 so that $\mathrm{H}_{4}$ is received. These results indicated that the brand awareness variable was able to mediate the effect of celebrity endorsers on purchase intention. In connection with these results, it could be interpreted that celebrity endorsers BukaLapak (Mohammad Istiqamah Djamad "Payung Teduh") who is considered to have high credibility can increase brand awareness of consumers who shop online in the city of Denpasar, causing an increase in purchase intention or compelled to make purchases on the BukaLapak.com site. The results are consistent with previous research that is carried out by Susilo and Samuel (2015) explains that brand awareness is able to mediate the relationship celebrity endorser in advertising with the intention to buy.The results of this study reinforce previous studies conducted by Gunawan and Dharmayanti (2014).

\section{Conclusion}

Based on the results of data analysis and discussion of the effects of each variable that has been described, then some conclusions can be drawn as follows: 1). Celebrity endorsers influence positively and significantly to brand awareness. The result of research shows that higher credibility celebrity endorser who used PT. BukaLapak as an ad star, the higher the consumer brand awareness in the city of Denpasar, and vice versa if the credibility of celebrity endorsers is low, the brand awareness will also be lower; 2). Celebrity endorsers have a positive and significant impact on purchase intention. Results of the research signifies that higher credibility of celebrity endorsed who used PT. BukaLapak as an ad star, the higher the purchase intention of consumers in the city of Denpasar through the BukaLapak.com site, and vice versa if the credibility of celebrity endorser is low, the purchase intention will also be lower; 3). Brand awareness has a positive and significant effect on purchase intention. These results indicate that the higher consumer brand awareness in the city of Denpasar regarding PT. Bukalapak, then purchase intention through the site BukaLapak.com will also be higher, and vice versa if brand awareness is low, purchase intention is also to be increasingly low; 4). Brand awareness is able to mediate the influence of celebrity endorsers on purchase intention. These results indicate that the celebrity endorser BukaLapak who has high credibility is able to increase consumer brand awareness in the city of Denpasar so as to cause an increase in purchase intention or compelled to do purchase on BukaLapak.com site.

Suggestions that can be given to those who need it, celebrity endorsers who have high credibility are proven able to increase consumer brand awareness in the city of Denpasar on BukaLapak.com site. This, of course, can be a consideration for the management of PT. BukaLapak to maintain and develop the use of celebrity endorser in ads for the next in order to create brand awareness that is much higher again.

Purchase intention of consumers in Denpasar would be high not only due to credibility celebrity endorser alone but is followed by high brand awareness. Thus, PT. BukaLapak should pay attention to brand awareness improvement effortsin addition to present interesting commercials to further encourage more consumers who want to try shopping online at sites BukaLapak.com. Researchers further expected to conduct research with coverage that is more comprehensive, add more variables than in this research, and expected to add a reference to the variable that will be investigated.

\section{References}

Chen, Shih-Mei and Patricia Huddleston. 2009. A Comparison of Four Strategies to 
Promote Fair Trade Products.International Journal of Retail \& Distribution Managemen. 37(4): 336-345

Chi, Hsin Kuang, huery Ren Yeh dan Ya Ting Yang. 2009. The Impact of Brand Awareness on Consumer Purchase Intention: The Mediating Effect of Perceived Quality and Brand Loyalty. The Journal of International Management Studies, 4 (1): 135-144.

Dei, GustiAyu Theoria.2015. Peran Brand Image Memediasi Pengaruh Kredibilitas Celebrity Endorser Terhadap Purchase Intention.E-Jurnal Manajemen Unud, 4(5):1206-1228.

Fleck, Bhatany, Lisa.M Beckman, Heather D. Hussey, and Julian L. Strens. 2014. YouTube in the Classroom: Helpful Tips and Student Perceptions. The Journal of Effective Teaching 14 (3):21-37.

Gunawan,Fitri Anggraini dan Diah Dharmayanti.2014.Analisis Pengaruh Iklan Televisi Dan Endorser Terhadap Purchase Intention Pond's Men Dengan Brand Awareness Sebagai Variabel Intervening. Jurnal Manajemen Pemasaran Petra, 2(1):1-14.

Gupta, R. Kishore, N. Verma, D. (2015). "Impact of Celebrity Endorsement on Consumers Purchase Intention: A Study of Indian Consumers". Australian Journal of Business and Management Research. Vol.05 No.03

Hsiao, Hsu, Chu, and Fang. 2014. Discussion of Whether Brand Awareness Is a Formof Marketing .International Journal of Business and Information. 9(1):50-61

Jung,Na Yong dan Yo Kyong Seock. 2016.The impact of corporate reputation on brand attitude and purchase intention. Spinger Oper, DOI 10.1186/s40691-016-0072-y:9-13.

Khoiruman, M. 2015. Pengaruh Tukul Arwana Sebagai Selebrity Endorser Terhadap Brand Awareness Masyarakat (Studi Kasus Iklan XL versi Tukul Arwana). Kelola, 2 (3): 2337- 5965.

Kiswati, Sri. 2010. Studi Tentang Sikap Konsumen Atas Merek Tolak Angin pada Mahasiswa/I Fakultas Ekonomi Undip Semarang. Program Study Magister Manajemen Program Pasca Sarjana. Universitas Diponegoro Semarang.

Kotler, Philip dan Gary Armstrong. 2012. Prinsip-prinsip Pemasaran. Edisi 13.Jilid 1.Jakarta: Erlangga. 454p.

Kristyamoko, Y. W., dan Andjarwari, L.A. 2013. Pengaruh Persepsi Kualitas Tahapan Niat Beli Tablet Samsung Galaxy Tab, Jurnal Ilmu Manajemen, 1 (3): 34-48

Liu, Matthew Tingch. 2007. Relations Among Attractiveness Of Endorsers, Match-up, and Purchase Intention In Sport. Journal of Consumer Marketing. 24 (6): 361-370

Mberia, Dr. Hellen. K. 2014. The Effects OF Celebrity Endorsement in Advertisements.International Journal of Academic Research in Economics and Management Sciences, 3 (5): 2226-3624.

Merriska, Augustine dan Mustika Sudiati Purnanegara. 2012. The Relationship 
Between Tv Advertising Cost And Brand Awareness For Food Product Category In Indonesia (Februari 2010). Journal of Business And Management, 1 (1): 90-94.

Ohanian, Roobina. 1990. "Construction and Validation of Scale to Measure Celebrity Endorsers Perceived Expertise, Trustworthiness, and Attractiveness". Journal of Advertising. ABI/INFORM Research. 19 (3):39-52.

Petahiang,I.L.,Peggy M.P.,and Worang,F.G.2015.The Influence of Brand Awareness and Preceived Risk Toward Costumer Puschase Intention on Online Store. Journal Berkala Ilmiah Efisiensi, 15 (4):126-133.

Pornpitakpan, Chantika. 2003. Validation of Celebrity Endorser, Credibility Scale: Evidence from Asians. Journal of Marketing. 19 (2):179-195

Putra, I Ketut Triyana Darma.2015. Peran Brand Image Dalam Memediasi Pengaruh Celebrity Endorser Terhadap Niat Beli. E-Jurnal Manajemen Unud, 4 (6): 1722-1734.

Putra, I M.S.M dan Giantari, I. G.A.K. 2014.Pengaruh brand image, celebrity endorser kualitas produk, dan kewajaran harga terhadap niat membeli Sepeda Motor Matic Merek Honda di Kota Denpasar. E-Journal Manajemen Universitas Udayana 3 (10): 28692886.

Roozy,E.,A.R.Mohammad,dan V.Husein. 2014. Effect of Brand Equity On Consumer Purchase Intention. Indian J.Sci, 6 (3):212-217.

Ruhamak, M. Dian dan Budi Rahayu. 2016. Pengaruh Word Of Mouth Terhadap Purchase Intention Melalui Brand image Pada Lembaga Kursus Bahasa Inggris Dynamic English Course Pare. Jurnal Ekonomi Universitas Kediri, 1 2):188-204.

Sharifi, Seyed Shahin. 2014. Impacts Of The Trilogy Of Emotion On Future Purchase Intentions In Products Of High Involvement Under The Mediating Role Of Brand Awareness. European Business Review, 26 (1): 58-59.

Shimp, A Terence 2014. Komunikasi Pemasaran Terpadu Dalam Periklanan dan Promosi.Salemba Empat.

Suki, Norazah Mohd. 2014. Does Celebrity Credibility Influence Muslim and nonMuslim Consumers Attitudes Toward Brands and Purchase Intention. Journal Islamic and Marketing, 5 (2): 235-240

Tulasi, Dominikus. 2012. Marketing Comunication Dan Brand Awareness.Humaniora, 3 (1): $215-222$.

Wiryawan, Zahrida Z. dan Ria E. Monarch. Pengaruh Brand Awareness Terhadap Perceived Quality Dan Brand Royalti Sebagai Determinan Terhadap Purchase Intention. Jurnal Manajemen, 16 (3): 299-311. 